\title{
Thrust-Induced Collapse of Mountains- An Example from the "Big Bend" Region of the San Andreas Fault, Western Transverse Ranges, California
}

By Karl S. Kellogg

Scientific Investigations Report 2004-5206 


\section{U.S. Department of the Interior \\ Gale A. Norton, Secretary \\ U.S. Geological Survey \\ Charles G. Groat, Director}

U.S. Geological Survey, Reston, Virginia: 2004

For sale by U.S. Geological Survey, Information Services
Box 25286, Denver Federal Center
Denver, CO 80225
For more information about the USGS and its products:
Telephone: 1-888-ASK-USGS
World Wide Web: http://www.usgs.gov/

Any use of trade, product, or firm names in this publication is for descriptive purposes only and does not imply endorsement by the U.S. Government.

Although this report is in the public domain, permission must be secured from the individual copyright owners to reproduce any copyrighted materials contained within this report. 


\section{Contents}

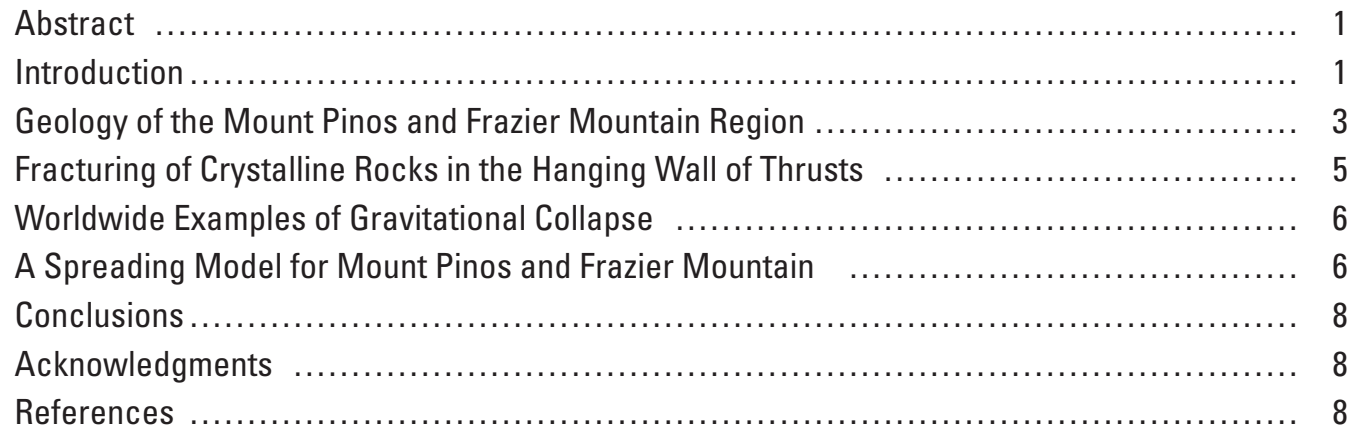

\section{Illustrations}

1. Regional geologic map of the western Transverse Ranges of southern

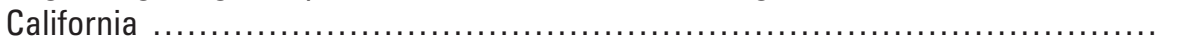

2. Simplified geologic map of the Mount Pinos-Frazier Mountain region $\ldots \ldots \ldots \ldots \ldots 2$

3. View looking southeast across the San Andreas rift valley toward

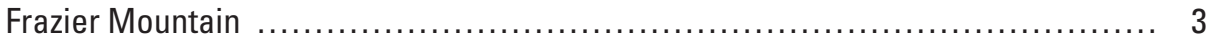

4. View to the northwest of Mount Pinos, the rift valley (Cuddy Valley) of the San Andreas fault, and the trace of the Lockwood Valley fault ............... 3

5. View to the northeast of Frazier Mountain, showing the trace of the Frazier Mountain thrust

6. Photograph, facing north, of hills underlain by Pleistocene landslide deposits

7. Photograph showing typical roadcut along Mount Pinos Road that exposes the highly fractured, cataclastically deformed, and argillically altered biotite gneiss

8. Equal-area, lower-hemisphere, stereographic projection of (A) poles to fractures measured along Mount Pinos Road and

(B) poles to foliation measured throughout the Mount Pinos Massif

9. Three models for gravitational spreading of mountains after (A) Beck (1968), (B) Mahr (1977), and (C) Kellogg (2001b)

10. Proposed models for gravitational spreading of the Mount Pinos and Frazier Mountain massifs 7

11. View toward Liebre Mountain facing southeast from Interstate Highway 5 ....... 8 


\title{
Thrust-Induced Collapse of Mountains-An Example from the "Big Bend" Region of the San Andreas Fault, Western Transverse Ranges, California
}

\author{
By Karl S. Kellogg
}

\section{Abstract}

Mount Pinos and Frazier Mountain are two prominent mountains just south of the San Andreas fault in the western Transverse Ranges of southern California, a region that has undergone rapid Quaternary contraction and uplift. Both mountains are underlain, at least in part, by thrusts that place granitic and gneissic rocks over sedimentary rocks as young as Pliocene. Broad profiles and nearly flat summits of each mountain have previously been interpreted as relicts of a raised erosion surface. However, several features bring this interpretation into question. First, lag or stream gravels do not mantle the summit surfaces. Second, extensive landslide deposits, mostly pre-Holocene and deeply incised, mantle the flanks of both mountains. Third, a pervasive fracture and crushed-rock network pervades the crystalline rocks underlying both mountains. The orientation of the fractures, prominent in roadcuts on Mount Pinos, is essentially random. "Hill-and-saddle" morphology characterizes ridges radiating from the summits, especially on Mount Pinos; outcrops are sparse on the hills and are nonexistent in the saddles, suggesting fractures are concentrated in the saddles. Latest movement on the thrusts underlying the two mountain massifs is probably early Quaternary, during which the mountains were uplifted to considerably higher (although unknown) elevations than at present. A model proposes that during thrusting, ground accelerations in the hanging wall, particularly near thrust tips, were high enough to pervasively fracture the hanging-wall rocks, thereby weakening them and producing essentially an assemblage of loose blocks. Movement over flexures in the fault surface accentuated fracturing. The lowered shear stresses necessary for failure, coupled with deep dissection and ongoing seismic activity, reduced gravitational potential by spreading the mountain massifs, triggering flanking landslides and producing broad, flat-topped mountains. This study developed from mapping in the western Transverse Ranges as part of the U.S. Geological Survey's Southern California Areal Mapping Project (SCAMP).

\section{Introduction}

The "Big Bend" region of the San Andreas fault (SAF), in the western Transverse Ranges of southern California (fig. 1), is a zone of relatively large transpression due to the left-stepping, right-slip fault geometry (Davis, 1983). This transpression has produced widespread thrusting and folding, both north and south of the SAF, that has significantly increased crustal thickness (for example, Namson and Davis, 1988). South of the SAF, the locus of contractional tectonism has apparently migrated south during the Quaternary to the Santa Barbara Channel (Rockwell, 1983), where folding and thrusting are currently active. In a roughly mirror-image scenario, thrusting north of the SAF has migrated northward with time, with a large component of shortening accommodated along the south-dipping Pleito-Wheeler Ridge fault system (Davis, 1983).

In concert with thrusting, the western Transverse Ranges have been uplifted rapidly during the Quaternary, with rates of uplift estimated at 4-8 millimeters per year (Yeats, 1983). This rapiduplift has been accompanied by rapid erosion and dissection, as shown by thick Quaternary basin-fill and mountain-flanking deposits adjacent to most of the mountain uplifts (see Dibblee, 1982).

The author of this paper proposes a model in which hanging-wall rocks were weakened by widespread fracturing that resulted from movement along low- to moderate-angle thrusts that placed brittle, crystalline rocks of Cretaceous and early Proterozoic age over structurally weak, mostly fluvial sedimentary rocks of the Miocene Caliente and Pliocene Quatal Formations. Uplift and erosion during and subsequent to thrusting and the resulting steepening of the mountain flanks, possibly driven by ongoing seismic activity, promoted episodic gravitational collapse of the mountains.

The proposed model is speculative for several reasons, mostly due to the difficulty of constraining the ages of either thrusting or the inferred associated gravitational collapse. Despite these difficulties (which will be discussed further), one objective of this paper is to provide a testable alternative to the conventional paradigm for peneplained mountaintop surfaces (see Dibblee, 1982) in active tectonic environments. This study evolved from mapping in the region as part of the U.S. Geological Survey's Southern California Areal Mapping Project (SCAMP). 


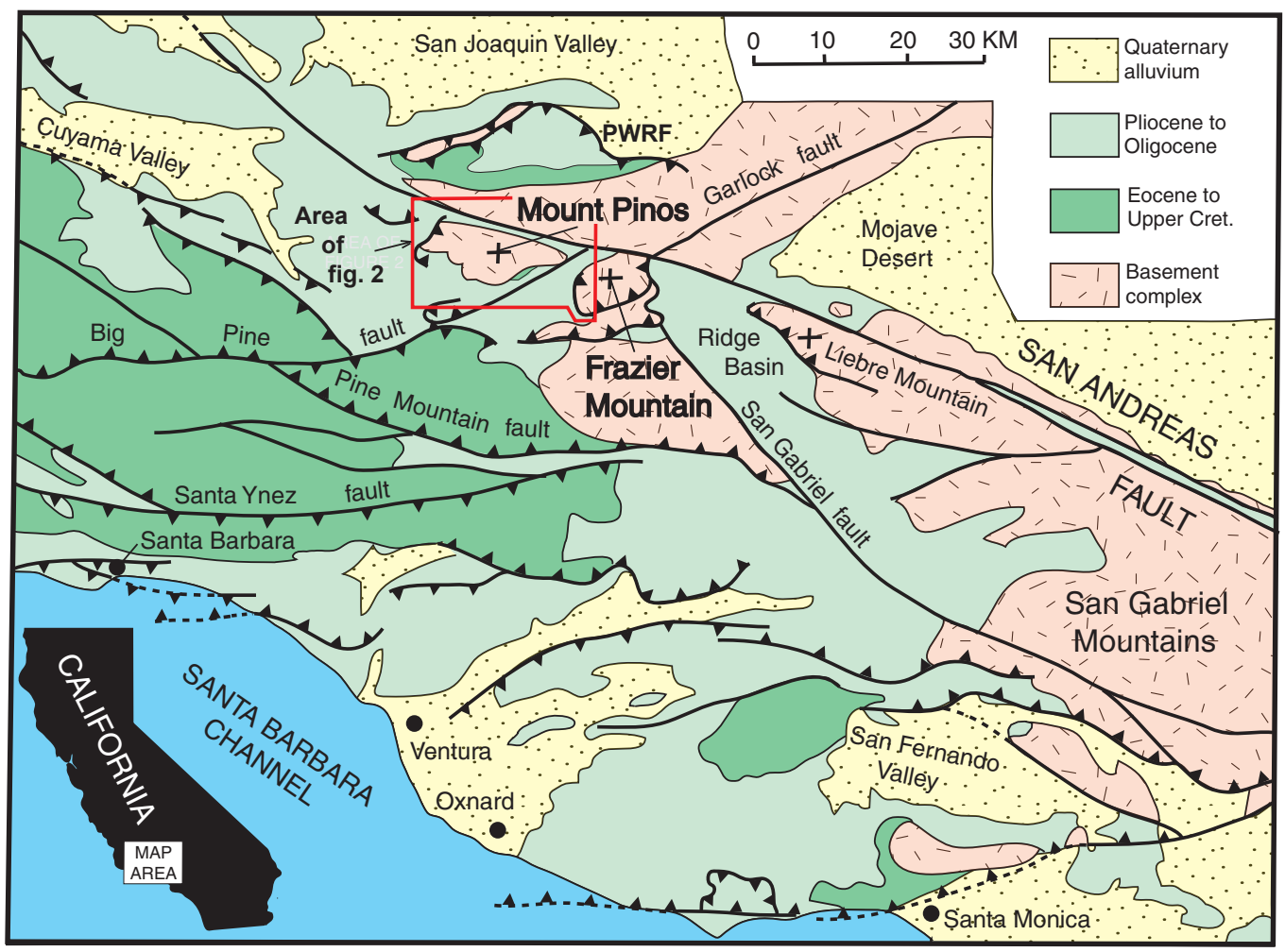

Figure 1. Regional geologic map of the western Transverse Ranges of Southern California, showing the Big Bend region of the San Andreas fault and the location of Mount Pinos and Frazier Mountain, modified from Jennings and Strand (1969) and Dibblee (1982). Faults showing teeth are thrust or reverse faults, with the teeth in the hanging wall. PRWF is the Pleito-Wheeler Ridge fault.

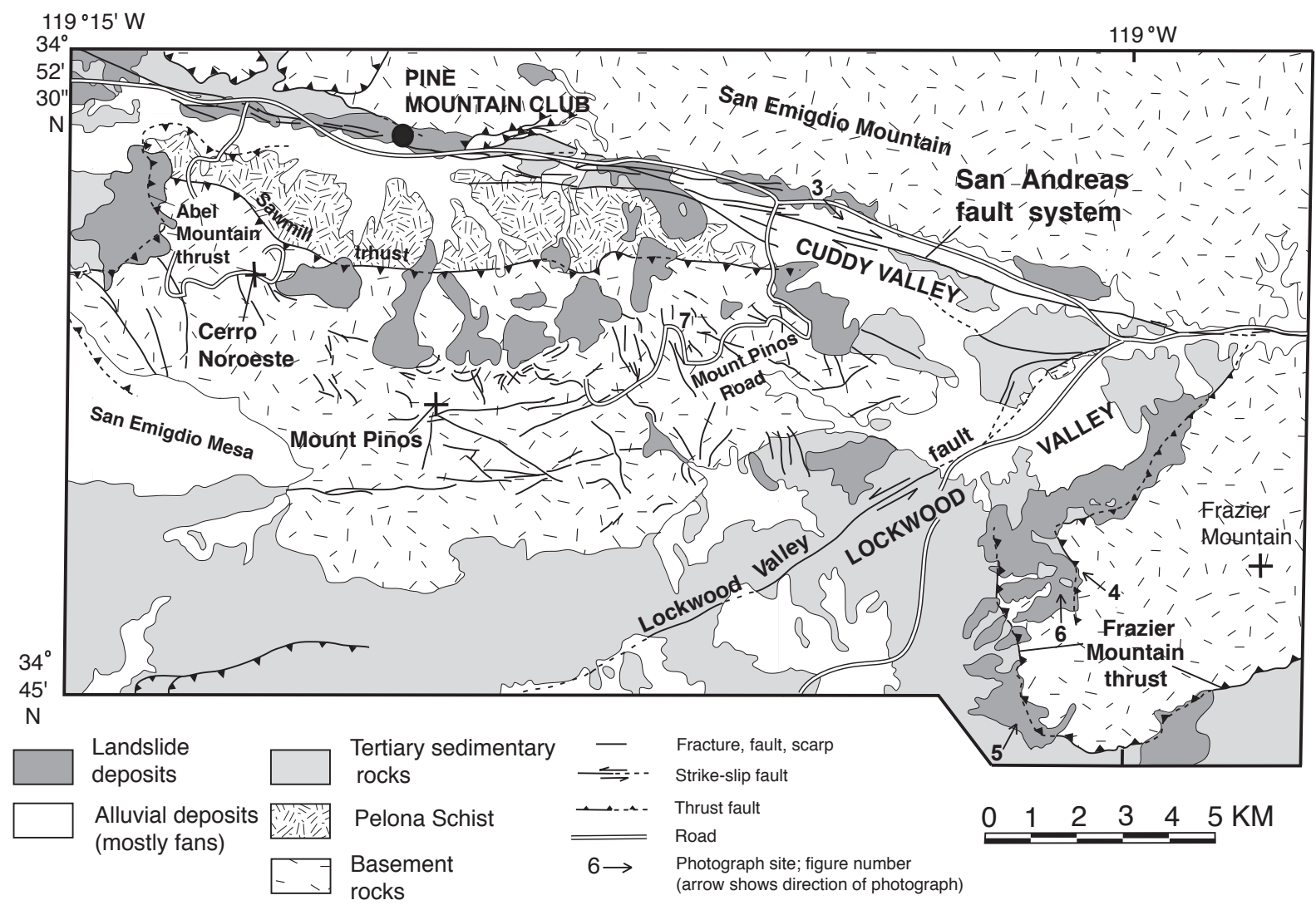

Figure 2. Simplified geologic map of the Mount Pinos-Cerro Noroeste region. The camera position for photograph site 4 is about 2 kilometers southwest of position shown. Modified from Kellogg (1999, 2003) and Kellogg and Miggins (2002). The Lockwood Valley fault was formerly known as the eastern end of the Big Pine fault (Minor and Kellogg, 1997). 


\section{Geology of the Mount Pinos and Frazier Mountain Region}

Mount Pinos and Frazier Mountain are two prominent, flat-topped mountain masses just south of the SAF (fig. 1). Cerro Noroeste is a westward high point, connected by a ridge to Mount Pinos (fig. 2). North of the SAF, the San Emigdio Mountains form a low (up to 2,210 m), rounded ridge parallel to the SAF. The SAF system occupies a broad east-striking valley (Cuddy Valley) that diverges from the overall northeaststriking trend of the fault system (Dibblee, 1982; Davis and Deubendorfer, 1987), thereby forming the "Big Bend" in the fault system. The "Big Bend" reach of the SAF has ruptured at least three times in the last 500 years (Davis, 1983; Davis and Deubendorfer, 1987), the last time being the large-magnitude 1857 Fort Tejon earthquake (estimated minimum $\mathrm{M}=8.25$; Sieh, 1978). Scarps and pressure ridges as high as $8 \mathrm{~m}$, probably associated with the 1857 earthquake, are prominent features in Cuddy Valley along the SAF (fig. 3).

Mount Pinos (fig. 4) and Frazier Mountain (figs. 3 and 5) rise to $2,605 \mathrm{~m}$ and 2,365 m, respectively; each is characterized by a wide, low profile and large (several square kilometers), nearly flat summit. The mountain flanks are mostly gentle, typically less than $20^{\circ}$. Exceptions are slopes on the north sides, facing the SAF, which are steep and locally form cliffs as high as about $50 \mathrm{~m}$. Extensive landslide deposits cover large areas on the flanks of both mountain massifs. Although historical landslides have occurred at several places on Mount Pinos (Kellogg and Miggins, 2002), most landslide deposits on both mountain massifs are long inactive; extensive landslide deposits on Frazier Mountain are Pleistocene in age (Zhou, 1990). The deposits lack identifiable breakaway zones, transverse ridges, or scarps and are deeply dissected (fig. 6). They are "relict" slides in the terminology of Cruden and Varnes (1996).

The relatively flat summits have been interpreted as remnants of a late Tertiary erosional surface (Dibblee, 1982; Davis, 1983), but there are reasons to doubt this interpretation (Kellogg, 2001a). The surface on Mount Pinos lacks lag gravels, which does not preclude the existence of an erosional surface, but neither does it support such an interpretation. Deposits interpreted as relict Pleistocene gravels have been mapped on the flanks of Frazier Mountain (Zhou, 1990), but these gravels have a provenance similar to gravels in the Miocene Caliente Formation, which is locally exposed on the flanks of the mountain (Carman, 1964; Kellogg, 2003). The clasts within the gravel consist of a bimodal population of (1) locally derived, angular augen gneiss, biotite gneiss, and vein quartz as long as $1 \mathrm{~m}$; and (2) well-rounded, fine- to mediumgrained granitoid rocks, intermediate volcanic rocks, and chert clasts as long as $20 \mathrm{~cm}$. The second clast population, most of which does not have a local source, is similar to that of the Caliente Formation in Lockwood Valley and on the west side of Frazier Mountain (Carman, 1964). This similarity in clast type and lack of local source terrains suggest that the well-rounded, Caliente-like gravel clasts may be second generation, derived from erosion of the Caliente Formation, and not relicts of a late Tertiary erosion surface.

Thrusting is presently inactive in the Mount Pinos and Frazier Mountain region; the latest movement was during the

Figure 3. View looking southeast across the San Andreas rift valley toward Frazier Mountain. A scarp probably produced during the 1857 Fort Tejon earthquake is visible at the extreme right side of the photograph.
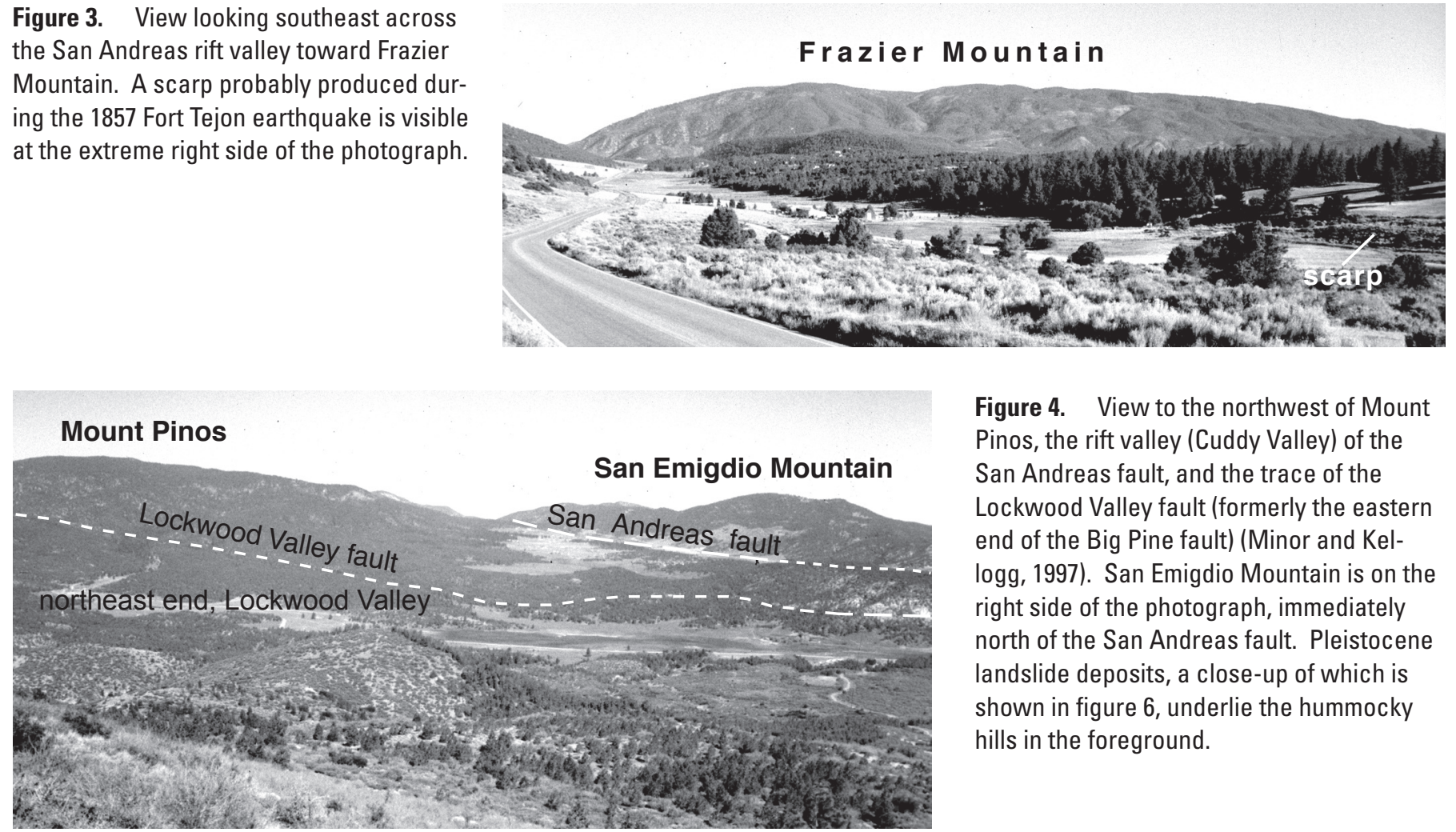

Figure 4. View to the northwest of Mount Pinos, the rift valley (Cuddy Valley) of the San Andreas fault, and the trace of the Lockwood Valley fault (formerly the eastern end of the Big Pine fault) (Minor and Kellogg, 1997). San Emigdio Mountain is on the right side of the photograph, immediately north of the San Andreas fault. Pleistocene landslide deposits, a close-up of which is shown in figure 6, underlie the hummocky hills in the foreground. 


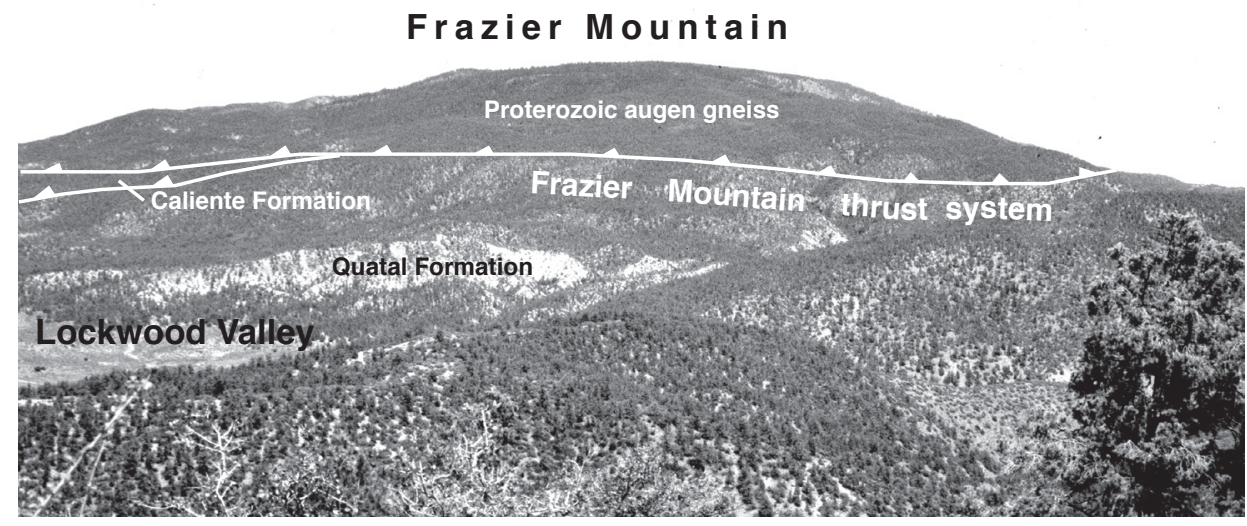

Figure 5. View to the northeast of Frazier Mountain, showing the trace of the Frazier Mountain thrust.

Figure 6. Photograph, facing north, of hills underlain by Pleistocene landslide deposits that locally contain clasts of Proterozoic augen gneiss as long as several meters. The morphology of the hills is largely due to post-landslide dissection.
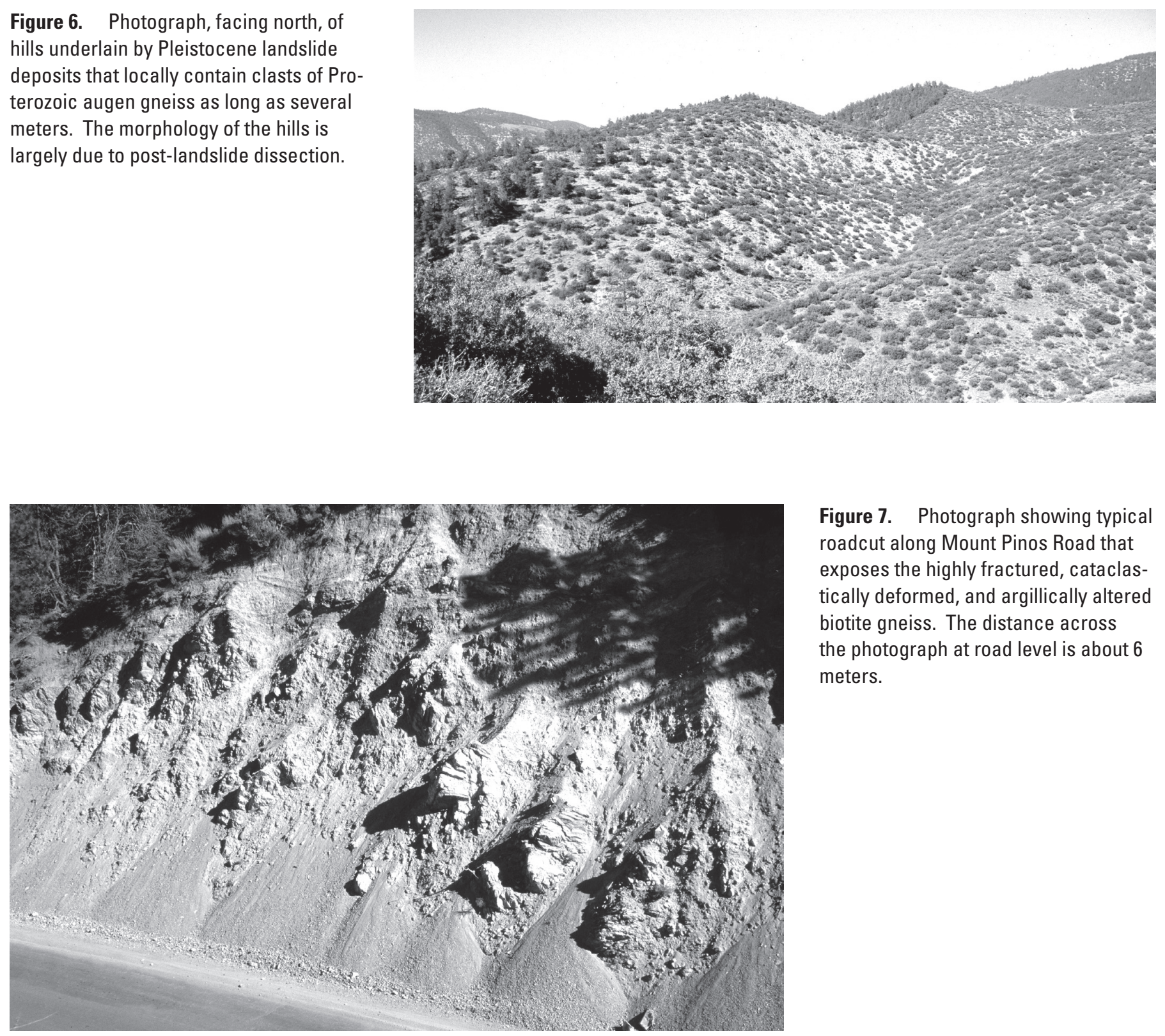

Figure 7. Photograph showing typical roadcut along Mount Pinos Road that exposes the highly fractured, cataclastically deformed, and argillically altered biotite gneiss. The distance across the photograph at road level is about 6 meters. 
early Pleistocene (Dibblee, 1982). Early Proterozoic augen gneiss (and lesser amounts of biotite schist and gneiss and felsic gneiss) that underlies most of Frazier Mountain is thrust over rocks as young as Pliocene along the Frazier Mountain thrust (Carman, 1964; Crowell and others, 1964; Kellogg, 1999) (fig. 5). Cretaceous granitic intrusive rocks, Cretaceous gneiss, and the Paleocene Pelona Schist (Ehlig, 1974; Kellogg and Miggins, 2002) that underlie the Mount Pinos massif are likewise thrust westward along the Abel Mountain thrust over Miocene terrigenous sediments of the Caliente Formation (Crowell and others, 1964; Davis, 1983; Kellogg and Miggins, 2002). The southern extent of the Abel Mountain thrust is concealed beneath the surface of San Emigdio Mesa and its continuation southeastward on the south side of the massif (fig. 2) is uncertain.

\section{Fracturing of Crystalline Rocks in the Hanging Wall of Thrusts}

Crystalline rocks in the hanging wall of both the Frazier Mountain thrust and the Abel Mountain thrust display a pervasive fracture network, which is generally not exposed at the surface on either Mount Pinos or Frazier Mountain. However, in fresh roadcut exposures along Mount Pinos Road, the fractures are well exposed and form wide (some more than $10 \mathrm{~m}$ ) zones of gouged rock and intervening zones of rock containing fractures in a seemingly random orientation (fig. 7). All gouge zones consist of crushed crystalline rock that has largely altered to clay and is moderately oxidized to an orange-tan color. The spacing of the fractures in the roadcuts is at millimeter to meter scale. The ground surfaces above the roadcuts contain mostly grus-rich soil and colluvium, although isolated tors of variably weathered granitic and gneissic rocks crop out in a scattered and irregular array. The relationships in the roadcuts suggest that the grussy areas between these outcrops are underlain by intensely fractured and sheared rock that is susceptible to deep weathering.

Regionally, the fractures or faults appear to form a cobweblike mosaic of crushed rock or gouge zones, the individual strands of which are short (generally less than 1 meter to several hundred meters). Numerous ridges that form hills and saddles also suggest the widespread fracture network. The summits of the hills commonly contain scattered outcrops, although outcrops are extremely rare on the grus-covered saddles. In addition, the "hill-and-saddle" morphology of the ridges is rarely linear in plan view and the saddles are rarely aligned, which suggests a lack of control by throughgoing faults. Speculatively, the saddles are interpreted to contain dense fractures on a scale of meters to tens of meters, whereas fractures under the hills are considered to be much less dense.

The extensive fractures were previously recognized but were attributed to undefined "regional stresses" (Dibblee, 1982). In order to test whether there is a correlation between fracture orientations and regional stress, 104 fracture orientations were measured in roadcuts along Mount Pinos Road (fig. 8A), from near its intersection with Cuddy Valley Road to a point about two-thirds of the way to the summit. The host rocks are medium-grained, foliated, granitic rocks and biotite orthogneiss. A preferred fracture orientation might be correlated to some regional stress, or it may reflect exploitation of consistently oriented, older planes of weakness, such as foliation. Random orientations collected over a large region would be more consistent with rock movement in numerous directions, as would occur during gravitational spreading.

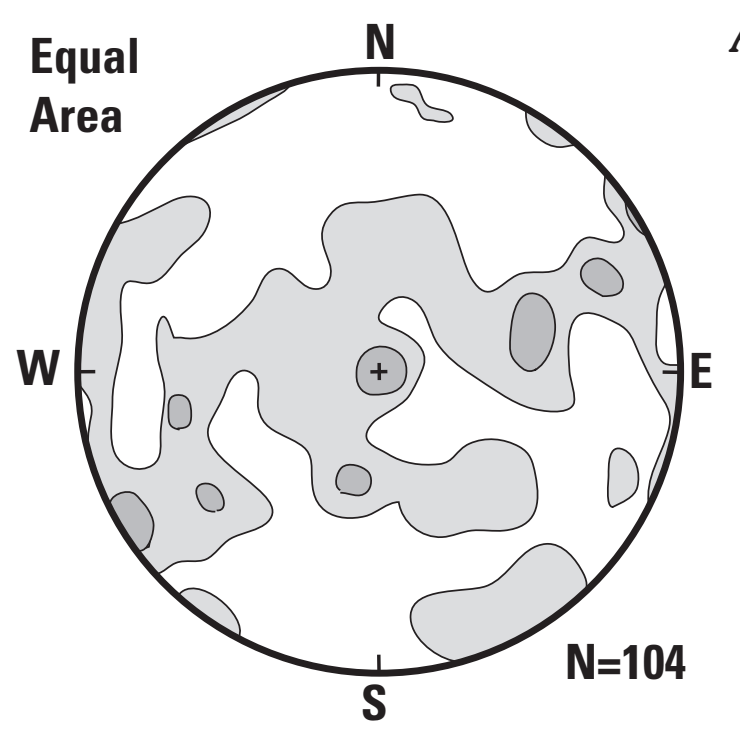

\section{Poles to fractures, Mount Pinos Road}

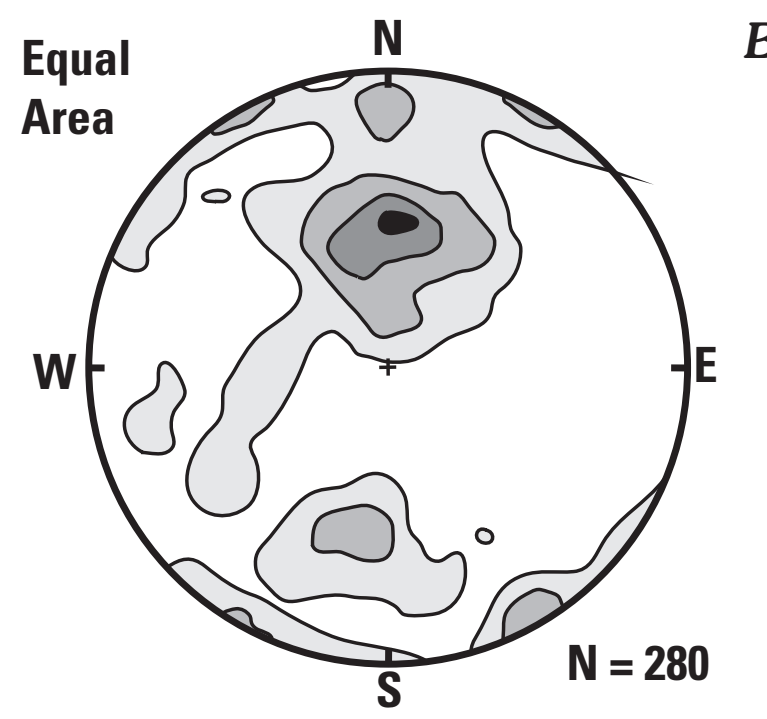

\section{Poles to foliation, Mount Pinos massif}

Figure 8. Equal-area, lower-hemisphere, stereographic projection of (A) poles to fractures measured along Mount Pinos Road and (B) poles to foliation measured throughout the Mount Pinos massif. Contoured on 2-, 4-, 6-, and 8-percent poles per 1-percent area. $\mathrm{N}$ is the number of observations. 
The results show a strongly dispersed spread of orientations, with a very weak development of a steep, east-northeast-striking girdle. The girdle orientation is oblique to the regional foliation, which is variable but generally strikes east-west with low to moderate dip (typically $20^{\circ}-60^{\circ}$; fig. 8B). The significance, if any, of the subtle east-northeast fracture trend is unclear.

A mappable network of fractures, scarps, and faults is exposed on Mount Pinos and Frazier Mountain. Many of these features are discernible on aerial photographs, and the more prominent ones are shown in figure 2. Some may be throughgoing joints with little offset, while others may reflect the gneissic foliation. However, many lineations are faults or fractures with demonstrable offset (Kellogg and Miggins, 2002).

Subtle linear scarps or sackungen (Beck, 1968; Varnes and others, 1989), both uphill- and downhill-facing and as long as several hundred meters, are locally preserved. The presence of sackungen indicates deep-seated rock creep, although all sackungen are eroded and appear to be inactive. Locally on some slopes, scarps bound relatively horizontal surfaces on the downhill side, suggesting deep-seated rotational slumps.

Some scarps are located on the nearly flat summit surface near the northern steep face of the Mount Pinos-Cerro Noroeste massif and are clearly related to the gravitationally induced extension adjacent to the north face (fig. 2). The scarps may represent the locus of future landslide movement. Large landslide deposits have accumulated at the base of the north face, and active landsliding within the past few decades is evident in some places on the east face.

\section{Worldwide Examples of Gravitational Collapse}

Gravitational spreading has been recognized at a variety of scales, from entire orogens to individual mountain ranges. As an example of orogen-scale collapse, the Tibetan plateau is apparently spreading in an approximate east-west direction concurrent with north-south contraction and lithospheric thickening caused by underthrusting of the Indian subcontinent beneath the Tibetan plateau (England and Houseman, 1989; Coleman and Hodges, 1995). Similarly, during the middle Eocene to early Miocene, the Cordilleran fold-and-thrust belt of western North America apparently collapsed gravitationally following Late Cretaceous and early Tertiary thrusting and crustal thickening (Constenius, 1996).

Several models for gravitational spreading at individualmountain scales are outlined in figure 9. In some cases such spreading has been directly related to seismic activity. For example, ridge-crest spreading and widespread landsliding in the Santa Cruz Mountains of California were directly induced during the 1989 Loma Prieta earthquake (Ponti and Wells, 1991). Ridge-crest grabens and uphill-facing scarps (sackungen) associated with spreading of the Stillwater Range in Nevada were formed during large earthquakes in both 1915 and 1954 (McCalpin, 1999). In the central Italian Alps, features attributed to gravitational spreading (including uphill- and downhill-facing scarps, ridge-crest grabens, and linear troughs) have been attributed to paleoseismic events as young as late Holocene (Onida and others, 1999).

An excellent analogue to the Mount Pinos and Frazier Mountain region is in the Williams Fork Mountains of central Colorado (fig. 9C). In this case, highly fractured Precambrian crystalline rocks in the hanging wall of a large, low-angle, Late Cretaceous to early Tertiary ("Laramide") thrust (Williams Range thrust) overlie incompetent, mostly argillaceous Cretaceous rocks (Tweto and others, 1978; Kellogg, 2001b). The Williams Fork Mountains have a generally rounded morphology, the crystalline rocks are highly fractured, and active, uphill-facing scarps and ridge-top trenches (sackungen) are common. These features indicate ongoing gravitational spreading and collapse (Varnes and others, 1989). A model for formation of the widespread fracturing proposes that Laramide thrusting moved brittle hanging-wall rocks across a flexure in the thrust surface at approximately the crystalline cover-rock contact in the footwall and placed them above the relatively incompetent Cretaceous rocks (Kellogg, 2001b). After uplift and erosion, the weakened, fractured hanging-wall rocks spread gravitationally, resulting in widespread landslide deposits along the mountain flanks. Most of the deposits are currently inactive but may have been active in the late Pleistocene when greater effective moisture increased pore-water pressure in bedrock fractures.

\section{A Spreading Model for Mount Pinos and Frazier Mountain}

The model proposes that, during late Pliocene and early Pleistocene thrusting along the Frazier Mountain and Abel Mountain thrusts, ground accelerations in the hanging wall created an environment conducive to rock shattering and crushing. Such ground accelerations are particularly intense in the hanging wall near thrust tips (Brune, 1999), the region where the thrust surfaces. Fracturing may have been accentuated by possible (but not currently recognized) flexures along the thrust surface upon which the brittle crystalline rocks in the hanging wall may have moved. Seismic shaking was enhanced by the juxtaposition of brittle rocks over soft, deformable sedimentary rocks of the Caliente and Quatal Formations.

The hanging-wall region was rapidly uplifted during the late Pliocene to early Pleistocene episode of thrusting at a rate that was considerably more rapid than at present. Ground acceleration during thrusting may have been augmented by strike-slip movement along the SAF. However, because most of the flanking landslide deposits appear to be considerably older than Holocene, most 

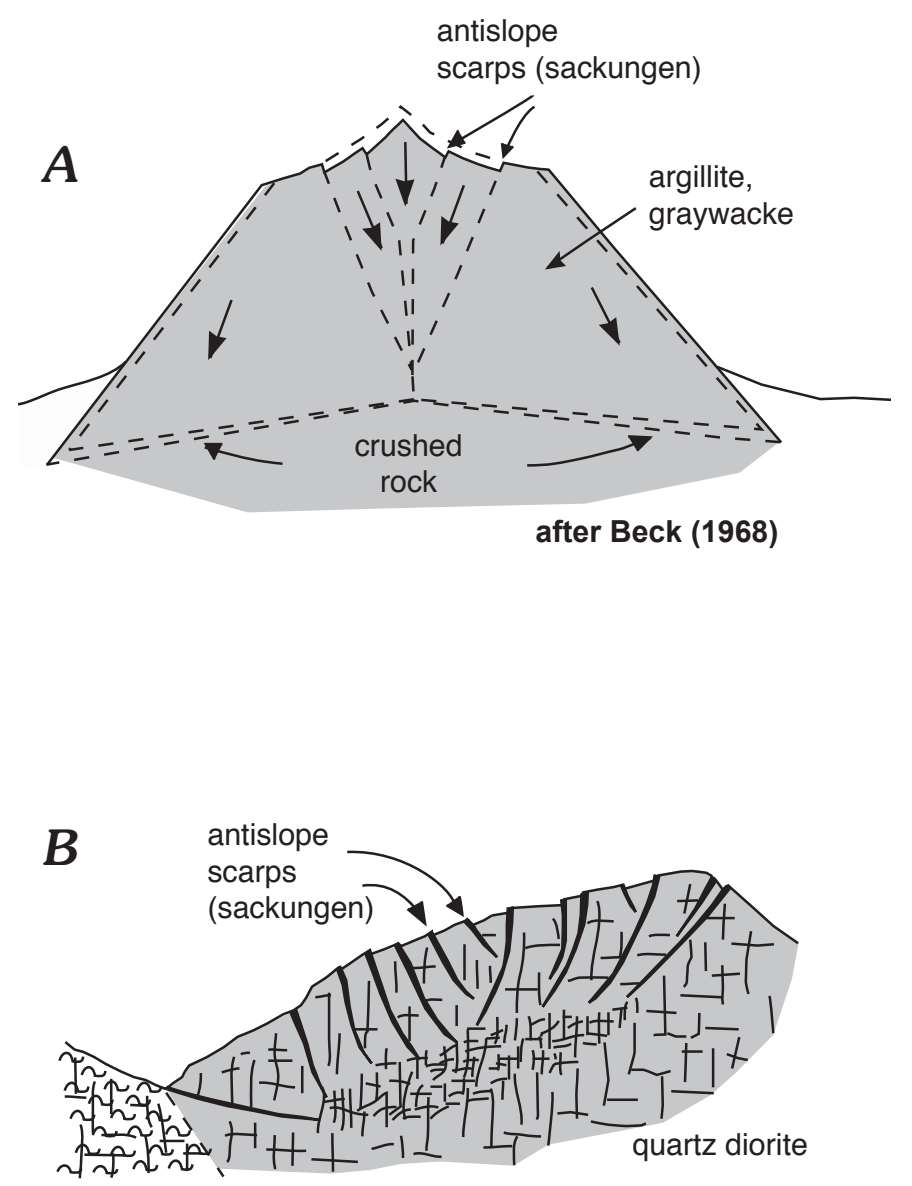

gneiss

after Mahr (1977)

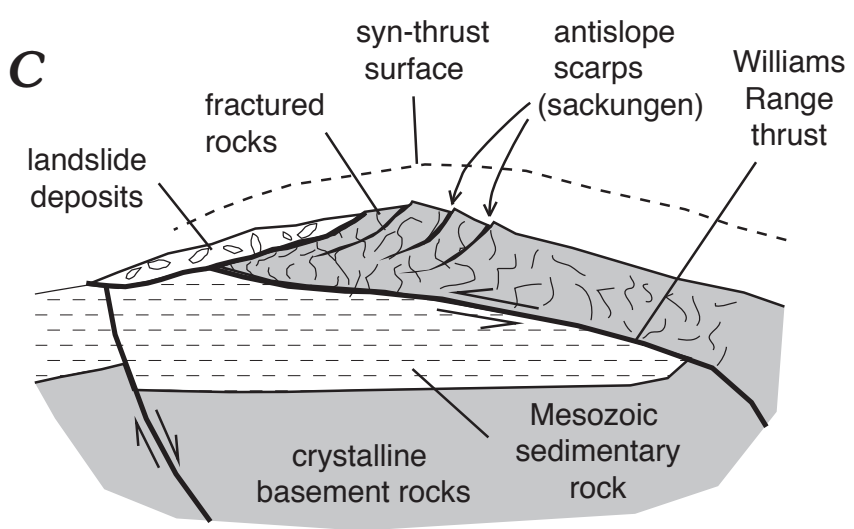

after Kellogg (2001b)

Figure 9. Three models for gravitational spreading of mountains, after (A) Beck (1968), (B) Mahr (1977), and (C) Kellogg (2001b). Distance across each diagram is $\sim 5-10$ kilometers.

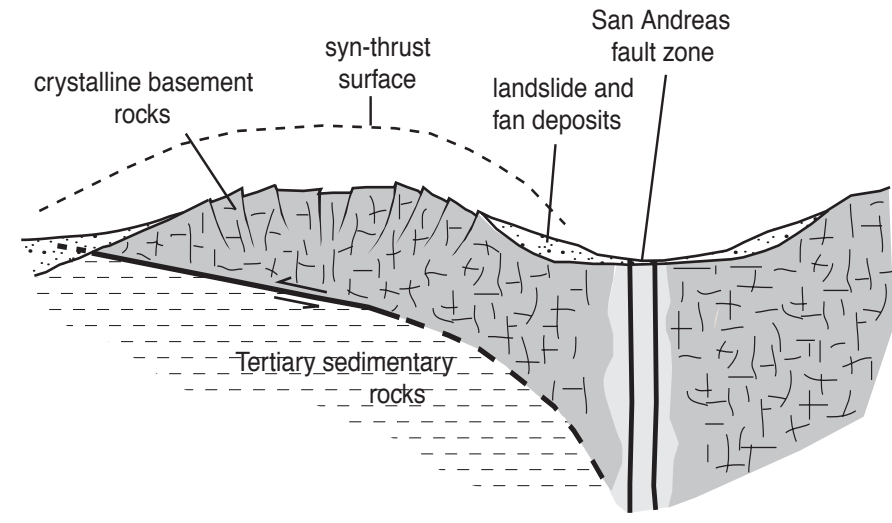

Figure 10. Proposed model for gravitational spreading of the Mount Pinos and Frazier Mountain massifs.

shattering and fracturing was probably related to the currently inactive thrusting.

Due to the lowered shear stresses necessary for failure, coupled with ongoing seismic activity, the gravitational potential of the uplifting mountain masses was significantly reduced by gravitational spreading, which was accentuated by deepening of the flanking valleys by erosion. The result was broad, nearly flat-topped mountains with numerous flanking landslide deposits. Figure 10 shows schematically this model for gravitational spreading.

Many questions regarding the proposed model remain unanswered, and until further work is done the proposed mechanism for gravitational collapse will remain speculative. Important questions revolve around (1) dating the exact timing of thrusting (Pliocene to probably early Pleistocene), (2) dating the timing of the pervasive fracturing that weakened the crystalline rocks underlying the mountains, and (3) establishing that these two events are coeval. Nonetheless, the observations are entirely consistent with a gravitationalspreading origin for Mount Pinos and Frazier Mountain and suggest that a similar mechanism may operate wherever brittle crystalline rocks have been thrust above weaker sedimentary rocks. Conversely, some observations, such as the lack of lag gravels on summit surfaces, are inconsistent with a peneplanation model.

One locality in particular, Liebre Mountain, about $25 \mathrm{~km}$ east of Frazier Mountain and just south of the San Andreas fault (fig. 1), appears to share many structural and geomorphic characteristics with Mount Pinos and Frazier Mountain (J.C. Crowell, University of California at Santa Barbara [Emeritus], oral commun., 2001) and may present a future opportunity to test the model for gravitational collapse. Liebre Mountain is broad with a wide, flat-topped summit region (fig. 11) and is bounded on the south and west by thrusts that place mostly Cretaceous granitic rocks above the Pliocene sedimentary rocks of the Ridge Basin (Jennings and Strand, 1969). 


\section{Conclusions}

A number of observations outlined in this paper support a model for gravitational spreading: (1) Mount Pinos and Frazier Mountain are rounded, nearly flat-topped mountain massifs, flanked by extensive, mostly pre-Holocene landslide deposits; (2) lack of direct evidence, such as lag gravels, indicates that the summits may not be remnants of old erosion surfaces, as has been previously suggested; (3) the crystalline rocks underlying both mountain massifs are pervasively fractured and crushed; (4) the crystalline rocks in most places along the margins of the mountains are thrust above easily deformable Miocene and Pliocene sandstone, mudstone, and shale; and (5) regionally, the area has undergone extremely rapid $(4-8 \mathrm{~mm} / \mathrm{yr})$ uplift rates.

These observations lead to the following proposed tectonic history: (1) the pervasive shattering of the crystalline rocks resulted from early Quaternary and late Pliocene thrusting, perhaps as a result of high accelerations resulting from movement over nonplanar surfaces in the thrust plane; (2) the weakened crystalline rocks spread gravitationally in response to local, thrust-induced uplift followed by rapid dissection, a process augmented by regional uplift; and

(3) spreading and mountain "flattening" may have been augmented by ongoing seismic activity along the SAF.

\section{Acknowledgments}

This study evolved as part of the U.S. Geological Survey's Southern California Areal Mapping Project (SCAMP). I am indebted to R.G. Bohannon, P.C. Carrara, S.A. Minor, R.R. Shroba, E.A. Keller, and I. Cemen for careful reviews of the manuscript that clarified numerous points. In particular, additional discussions with Minor and Keller encouraged me to proceed with presenting the ideas in this paper.

\section{References}

Beck, A.C., 1968, Gravity faulting as a mechanism of topographic adjustment: New Zealand Journal of Geology and Geophysics, v. 11, p. 191-199.

Brune, J.N., 1999, Rock shattering vs. crushing and shearing-Evidence for extreme ground motion on the hanging wall of thrust sheets: Geological Society of America Abstracts with Programs, v. 31, no. 6, p. A41.

Carman, M.F., Jr., 1964, Geology of the Lockwood Valley area, Kern and Ventura Counties, California: Sacramento, California Division of Mines and Geology Special Report $81,62 \mathrm{p}$.

Coleman, M., and Hodges, K., 1995, Evidence for Tibetan plateau uplift before $14 \mathrm{Myr}$ ago from a new minimum age for east-west extension: Nature, v. 374, p. 49-52.

Constenius, K.N., 1996, Late Paleogene extensional collapse of the Cordilleran foreland fold and thrust belt: Geological Society of America. Bulletin, v.108, p. 20-39.

Crowell, J.C., and 15 others, 1964, Preliminary geologic map of the Tejon Pass region, southern California, in Crowell, J.C., ed., The San Andreas fault from the Temblor Mountains to Antelope Valley, southern California: Society of Economic Paleontologists and Mineralogists and San Joaquin Geological Society 1964 Fieldtrip Guidebook, scale $1: 62,500$.

Cruden, D.M., and Varnes, D.J., 1996, Landslide types and processes, in Turner, A.K., and Schuster, R.L., eds., Landslides investigations and mitigation: Washington, D.C., National Academy Press, p. 36-75.

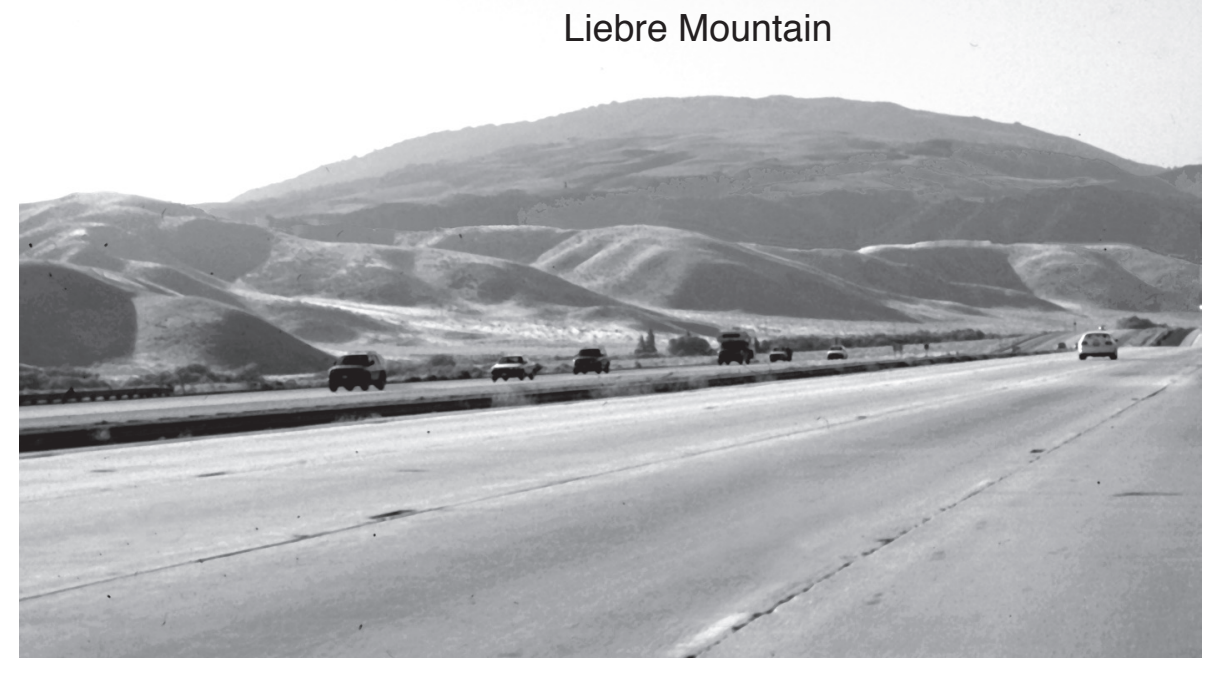

Figure 11. View toward Liebre Mountain facing southeast from Interstate Highway 5, 7 kilometers southeast of Tejon Pass. The trace of the San Andreas fault is about 1 kilometer north of the photograph location and passes to the left (north) side of Liebre Mountain. 
Davis, T.L., 1983, Late Cenozoic structure and tectonic history of the western "Big Bend" of the San Andreas fault and adjacent San Emigdio Mountains: University of California at Santa Barbara, Ph.D. dissertation, 563 p.

Davis, T.L., and Duebendorfer, E.M., 1987 Strip map of San Andreas fault, western Big Bend segment: Geological Society of America Map and Chart Series MC-60, scale $1: 31,682$.

Dibblee, T.W., Jr., 1982, Geology of the Alamo Mountain, Frazier Mountain, Lockwood Valley, Mount Pinos, and Cuyama Badlands areas, southern California, in Fife, D.L., and Minch, J.A., eds., Geology and mineral wealth of the California Transverse Ranges (Mason Hill Volume): Santa Ana, California, South Coast Geological Society, p. 57-77.

Ehlig, P.L., 1974, Causes of distribution of Pelona, Rand, and Orocopia schists along the San Andreas and Garlock faults, in Dickenson, W.R., and Grantz, A., eds., Proceedings of the Conference on Geologic Problems of the San Andreas Fault System: Stanford University Publication in the Geological Sciences 11, p. 294-306.

England, P., and Houseman, G., 1989, Extension during continental convergence, with application to the Tibetan plateau: Journal of Geophysical Research, v. 94, p. 17561-17579.

Jennings, C.W., and Strand, C.W., 1969, Geologic map of California, Los Angeles sheet (Olav P. Jenkins edition): California Division of Mines, scale 1:250,000.

Kellogg, K.S., 1999, Geologic map of the Lockwood Valley quadrangle, Ventura County, California: U.S. Geological Survey Open-File Report 99-130, scale 1:24,000.

Kellogg, K.S., 2003, Geologic map of the Cuddy Valley quadrangle, Kern and Ventura Counties, California: U.S. Geological Survey Open-File Report 03-153, scale 1:24,000.

Kellogg, K.S., 2001a, Seismogenic flattening of mountainsA possible example near the Big Bend of the San Andreas fault, southern California: Geological Society of America Abstracts with Programs, v. 33, no. 3, p. A30.

Kellogg, K.S., 2001b, Tectonic controls on a large landslide complex - Williams Fork Mountains near Dillon, Colorado: Geomorphology, v. 41, p. 355-368.

Kellogg, K.S., and Miggins, D.P., 2002, Geologic map of the Sawmill Mountain quadrangle, Kern and Ventura Counties, California: U.S. Geological Survey Open-File Report 02-406, scale 1:24,000.

Mahr, T., 1977, Deep-reaching gravitational deformations of high mountain slopes: Bulletin of the International Association of Engineering Geologists, v. 16, p. 121-127.
McCalpin, J.P., 1999, Episodic earthquake-induced movement on the Stillwater scarp "sackung," central Nevada: Geological Society of America Abstracts with Programs, v. 31, no. 7, p. 474.

Minor, S.A., and Kellogg, K.S., 1997, A smaller Big Pine fault-New interpretations of fault architecture in the western Transverse Ranges, southern California: EOS, Transactions of the American Geophysical Union, v. 78, no. 46, p. F700.

Namson, J.S., and Davis, T.L., 1988, Structure transect of the western Transverse Ranges, California-Implication for lithospheric kinematics and seismic risk evaluation: Geology, v. 16, p. 675-679.

Onida, M., Forcella, F., and Galandini, F., 1999, Recent slope deformations in the Valtellina region (Central Alps, Italy); an investigation by means of palaeoseismological techniques, in Szekely, B., Dunkl, I., Kuhlmann, J., and Frisch, W., eds., Geologie, palaeontologie, stratigraphie: Túbingen, Germany, Túbinger Geowissenschaftliche Arbeiten, v. 52, p. 191.

Ponti, D.J., and Wells, R.E., 1991, Off-fault ground ruptures in the Santa Cruz Mountains, California; ridge-top spreading versus tectonic extension during the 1989 Loma Prieta earthquake: Bulletin of the Seismological Society of America, v. 81, no. 5, p. 1480-1510.

Rockwell, T.K., 1983, Soil, chronology, geology, and neotectonics of the north-central Ventura Basin, California: University of California at Santa Barbara, Ph.D. Dissertation, $424 \mathrm{p}$.

Sieh, K.E., 1978, Slip along the San Andreas fault associated with the great 1857 earthquake: Seismological Society of America Bulletin, v. 68, p. 1421-1448.

Tweto, Ogden, Moench, R.H., and Reed, J.C., Jr., 1978, Geologic map of the Leadville $1^{\circ} \times 2^{\circ}$ quadrangle, northwestern Colorado: U.S. Geological Survey Miscellaneous Investigations Map I-999, scale 1:250,000.

Varnes, D.J., Radbruch-Hall, D.H., and Savage, W.Z., 1989, Topographic and structural conditions in areas of gravitational spreading of ridges in the Western United States: U.S. Geological Survey Professional Paper 1496, 28 p.

Yeats, R.S., 1983, Large scale Quaternary detachments in Ventura Basin: Journal of Geophysical Research, v. 88, p. 569-583.

Zhou, Xiaolin, 1990, Tectonic geomorphology and soil chronology of the Frazier Mountain area, western Transverse Ranges, California: University of California at Santa Barbara, Ph.D. dissertation, 184 p. 
Manuscript approved for publication September 28, 2004

Published in the Central Region, Denver, Colorado

Edited by Mary Kidd

Page layout, photocomposition by Amber Swallow

Graphics by the author 